\title{
Cervical Adenoid Basal Carcinoma
}

National Cancer Institute

\section{Source}

National Cancer Institute. Cervical Adenoid Basal Carcinoma. NCI Thesaurus. Code C40213.

A rare low grade carcinoma that arises from the cervix. It is characterized by the presence of nests of basaloid cells with focal glandular formations. 